\title{
The Role of Digital Transformation and Digital Innovation to SMEs Performance in Bali-Indonesia
}

\author{
Ni Putu Yeni Yuliantari ${ }^{1}$, Ni Made Wisni Arie Pramuki ${ }^{* 2}$ \\ ${ }^{*}$ Accounting Department, Faculty of Economics and Business, Universitas Hindu Indonesia, Bali-Indonesia
}

\begin{abstract}
When the Covid-19 pandemic hit Bali, the role of digital technology became important for organizations in dealing with consumer movements and the flow of goods. Through digital transformation, SME managers can provide a mechanism for SME innovation and performance. Using the theoretical resource-based view (RBV) framework, this study examines the mediating effect of digital innovation in the relationship between digital transformation and firm performance. Empirical data collected from 400 SME actors across the province of Bali reveals that digital transformation positively affects digital innovation and SME performance. Furthermore, our findings show that digital innovation positively affects SME performance and subsequently partially mediates the relationship of digital transformation to SME performance.
\end{abstract}

Keywords-Digital Transformation, Innovation, MSM performance

\section{INTRODUCTION}

The pressure of the global COVID-19 pandemic has not only resulted in a health crisis but also a crisis in the world economy. Countries in this world has implemented policies to control the spread of COVID-19, including contact tracing, isolation, quarantine, working from home, imposing restrictions on community activities, to large-scale social restrictions. Indonesia itself experienced an impact on social activities as a result of the restriction policy. COVID-19 has stopped economic activity because many companies are losing money and even closing their businesses, which has a big impact on layoffs.

Bali as a major tourist destination in Indonesia, has been greatly affected by the pandemic. Bali is a comfortable place for tourists to vacation both at the individual and group level, large events such as concerts or conferences are often held, now it cannot be done anymore due to the pandemic and the social restriction policy where people cannot interact closely. The direct impact of the COVID-19 pandemic is that many business units have temporarily closed their businesses (including hotels, travel agencies, and event planning services) or permanently closed their businesses in Bali. The tourism sector is the main pillar activity economy in Bali, has now stopped temporarily (Widnyani et al., 2021)

As data from Bank Indonesia (BI) of Bali Province shows that SMEs in Bali are experiencing severe pressure and paralysis caused by the drop in trading activity as a result of a $68 \%$ decline in sales, $12 \%$ capital difficulties, $10 \%$ distribution difficulties, $6 \%$ raw material difficulties and difficulty $4 \%$ production. The decline in sales turnover can also be caused by the characteristics inherent in SMEs such as limited capital, incomplete licensing, low awareness of paying taxes, weak innovation and low technology adoption (Kaimuddin, 2020; Pramuki, 2020; Sukarsa, 2020).

In this digital era, the need for digital transformation in various industries is an important phenomenon that cannot be avoided. Especially in the conditions of the Covid-19 pandemic, requiring major changes to the lifestyle and the way companies, including SMEs, work. SMEs need the role of digital technology to improve performance and productivity (Papadopoulos et al, 2020). Digital transformation is one of the main challenges facing businesses today (Sarikko et al., 2020). Digital transformation includes major changes that occur in 


\section{DOI: $\underline{10.51386 / 25815946 / 1 j s m s-v 4 i 6 p 102}$}

society and industry through the use of digital technology at the organizational level (Agarwal et al., 2010; Majchrzak et al., 2016).

Digital transformation is a comprehensive term that describes an organization's ability to leverage digital technology to increase the efficiency and effectiveness of its internal operations and external market offerings (Vial,2019). Digital transformation also drives innovation beyond organizational boundaries into external innovation networks (Prince et al., 2014; Westergren et al., 2019). Digital transformation is characterized by changes and transformations that are driven and built on a technological foundation (Nwankpa \& Roumani, 2016). Within an enterprise, digital transformation is defined as an organization's shift to big data, analytics, cloud, mobile and social media platforms. The current business environment is witnessing a radical change in the business landscape fuelled by the emergence of digital innovations and opportunities. Companies are increasingly adopting opportunities such as analytics, big data, cloud, social media and mobile platforms in an effort to build competitive digital business strategies. There is an increasing focus on digital business opportunities and strategies with practitioners and academics aiming to understand how companies can capitalize on digital opportunities and drive innovation and transformation across the enterprise (Markus \& Loebbecke, 2013; Westerman et al., 2014).

Previous literature on digital innovation suggests that several managerial challenges are associated with digital innovation and transformation. The introduction of digital technology can bring about restructuring of business processes, changes in system architecture, problem framing issues, and interactions between value chain partners (Abrell et al., 2016). Research from Nwankpa \& Roumani, (2016) reveals that digital transformation plays a more nuanced role by mediating the influence of IT capabilities and firm performance. Companies must recognize the importance of digital transformation and how to leverage the influence of IT capabilities in creating and driving enterprise performance (Henfridsson et al., 2018; Nambisan et al., 2019)

Innovation can be defined as the creation and discovery of new ideas, practices, processes, products or services (Daft, 1978). In an increasingly competitive business landscape, innovation is recognized as a key driver for companies seeking to create value and sustainable competitive advantage (Wang \& Wang, 2012). Innovation can be described into two levels, namely: improvement and new directions (Verganti, 2016). While improvement is a new solution that aims to optimally meet an existing value definition or an established problem (Verganti, 2016), a new direction of innovation is more radically creating a new set of value propositions and a new path. The emphasis on innovation has led to significant investigations by practitioners and researchers seeking to understand the role of innovation in firm performance (Datta \& Roumani, 2015). Not surprisingly, firms with greater innovation have shown a greater ability to develop new capabilities and respond to an evolving business climate leading to better performance (Calantone et al., 2002). The results of the study (Karagiannaki et al., 2017) reveal that innovation is a factor which is very important that drives the survival of the company.

Company performance is a measure of how well the company can meet its goals and objectives compared to its main competitors (Cao \& Zhang, 2011). In general, superior company performance is usually characterized by profitability, growth and market value (Cho \& Pucik, 2005). As might be expected, much scientific attention has been directed to understanding the causal structure of firm performance and explaining performance variations among competing businesses (March \& Sutton, 1997). According to Pramuki and Ayu (2020) financial performance reflects how the company's current condition is, if the company's financial performance is good then the company can generate maximum profits for the company.

Based on the explanation that this research is interesting to do. Given the low level of digital transformation for SME actors, it is necessary to study the perception of SME business actors in responding to the digitalization 
DOI: $\underline{10.51386 / 25815946 / \text { ijsms-v4i6p102 }}$

Volume: 4 Issue: 6

November to December 2021

https://www.ijsmsjournal.org

process into their business. This study modifies the model or framework that has been developed by Widjajanti (2009) by adding digital innovation as a mediating variable. To the knowledge of the researcher, this kind of model is still rarely used in the context of SMEs and makes this a motivation for researchers to understand the performance of SMEs in the midst of the COVID-19 pandemic. The use of the digital innovation variable as a mediating variable is the novelty of this research in order to produce more variation in the performance of SMEs comprehensive. The importance of studying this phenomenon is expected to be able to make an initial contribution to the development of SMEs, especially in the Province of Bali, especially in the context of digitalbased technology transformation to improve the competitiveness and performance of SMEs

\section{LITERATURE REVIEW}

\section{RESOURCE-BASED VIEW THEORY}

The resource-based view has been widely used in the information systems literature to explain how firms can gain competitive advantage and superior performance. The essence of this theory is that superior firm performance is caused by firm-specific resources and skills, rare, and difficult to imitate by competing firms (Barney, 1986; Bharadwaj, 2000). As a result, firms can achieve competitive advantage by acquiring or developing organizational capabilities that are rare, non-substitutable, and non-imitable (Barney, 1991; Amit \& Schoemaker, 1993). Furthermore, the theory assumes that the skills, capabilities, and other resources possessed by organizations differ between organizations and these resources are the main determinants of company performance. Thus, companies that are able to identify the characteristics of resources or capabilities that cannot be imitated by competitors will achieve a sustainable competitive advantage (Barney, 1991). Indeed, scholars have noted the importance of IT capabilities as a key organizational capability and consistent with the RBV view, found that IT capabilities that share the characteristics of scarcity, non-substitution and non-replication can drive superior firm performance (Wade \& Hulland, 2004; Chen, 2000). Nevertheless, in investigating how IT capabilities lead to superior performance, evidence suggests that variations in outcomes in firm performance can be explained by how IT capabilities leverage the value of other resources and capabilities within the organization (Ravichandran et al., 2005; Radhakrishnan et al., 2008). The perspective taken in this study is that IT capabilities are a valuable resource, but these IT resources can contribute indirectly by influencing other resources or capabilities within the company (Kohli \& Grover, 2008).

\section{DiGITAL TRANSFORMATION}

Digital technologies such as analytics, big data, cloud, social media, mobile platforms and smart solutions are driving innovations that are reshaping business models and reinvesting in the way organizations conduct business operations (Markus \& Loebbecke 2013; Westerman et al., 2014; Pagani, 2013). Digital transformation refers to changes and transformations that are driven and built on the foundation of digital technology. Within an enterprise, digital transformation is defined as an organization's shift to big data, analytics, cloud, mobile, and social media platforms. While organizations continue to transform and evolve in response to changing business landscapes, digital transformation is change that builds on the foundations of digital technology, ushering in unique changes in business operations, business processes, and value creation (Libert et al., 2016). For example, Libert et al. (2016) distinguish between digital enhancement, which is the use of digital technology to increase efficiency and effectiveness in a company's business processes, and digital transformation, which occurs when digital technology is used to radically change overall business operations, value creation and in some cases, new digital product offering case. Through digital transformation, organizations can integrate digital technology in many aspects of their operations and are also able to engage customers with emerging digital innovations (Aral \& Weill, 2007). Having traditional IT capabilities implies the ability to transition to emerging digital transformations (Anand et al., 2010). Anecdotal evidence shows that companies that have successfully implemented digital transformation are superior in generating revenue using existing resources (Westerman et al., 2014). Therefore, companies that have embraced digital transformation can effectively take advantage of the pervasive digital connections and communications among key partners in the value chain. 
DOI: $\underline{10.51386 / 25815946 / \text { ijsms-v4i6p102 }}$

Volume: 4 Issue: 6

November to December 2021

https://www.ijsmsjournal.org

\section{Digital INNOVATION}

Innovation has long been a central theme in the business strategy literature. Innovation can be defined as the creation and discovery of new ideas, practices, processes, products or services (Daft, 1978). Innovation is not routine, significant and involves changes to existing organizational competencies (Mezias \& Glynn 1993). In an increasingly competitive business landscape, innovation is recognized as a key driver for companies seeking to create value and sustainable competitive advantage (Wang \& Wang 2012). Innovation can be described in two levels: improvement and new directions (Verganti, 2016). While improvement is a new solution aimed at satisfying an existing definition of value or problem optimally (Verganti 2016), new direction innovation is more radical creating a new set of value propositions and new paths. The emphasis on innovation has led to significant investigations by practitioners and researchers alike seeking to understand the role of innovation in firm performance (Datta \& Roumani 2015). Not surprisingly, firms with greater innovation have shown a greater ability to develop new capabilities and respond to an evolving business climate leading to better performance (Calatone et al., 2002).

\section{SMEs PERFORMANCE}

Performance is a measure of how well a person or organization is able to meet the goals and objectives that have been set previously (Cao and Zhang 2011). In general, superior company performance is usually characterized by profitability, growth and market value (Cho \& Pucik, 2005). As might be expected, much scientific attention has been directed to understanding the causal structure of firm performance and explaining performance variations among competing businesses (March \& Sutton, 1997). In the context of SMEs, Aribawa (2016) states that SME performance is the result of hard work achieved by an individual and can be completed by that individual task in the company and in a certain period, and will be associated with a measure of value or standard of the company for which the individual works. Performance here itself is the achievement that will be obtained by a person or company that will achieved in a certain purpose. The success of an organization that realizes its goals strategic and predetermined by the behaviour that an organization would expect. In a good performance produced by an SME, it will be stronger to become the backbone of the economy and will play an increasingly important role in the national economy (Pramuki and Ayu,2020).

\section{The EfFect of Digital Transformation on SMEs Performance Province BALi}

As digital transformation accelerates, companies can achieve improved customer offerings through greater customization, increased customer satisfaction and reduced sales costs (Mithas et al., 2005; Brynjolfsson \& Hitt, 2000). Previous studies on the implications of digital technology have shown that digitization can positively affect a company's performance. Companies that use more digitally embedded business processes derive higher performance benefits from their IT capabilities (Brynjolfsson \& Yang, 1997). Digital integration between suppliers and value chain partners can reduce coordination costs (Malone, 1987) transaction costs (Williamson, 1975) and agency costs through improved communication, transparency and monitoring (Aral \& Weill 2007). Companies such as Best Buy and Starbucks leverage digital technology as they seek to improve performance through transformation of customer-side business operations and synchronization of data, information and ideas (Kovac et al., 2009; Setia et al., 2013). Therefore, we hypothesize as follows:

H1: Digital transformation has a positive effect on the performance of SMEs in Bali Province.

\section{THE EFFECT OF Digital TRANSFORMATION ON SMEs INNOVATION PROVINCE BALI}

Naturally, digital transformation enables organizations to leverage the widespread digital connections of people, data, information, and knowledge. Anecdotal evidence suggests that digital transformation nurtures digital business strategies that lead to process improvement and modularization (Bharadwaj et al., 2013). Digital transformation enables organizations to leverage the digital connections of people, data, information, and pervasive knowledge. Organizations that have embraced digital transformation are able to introduce new practices and innovative initiatives in their business operations (Díaz Chao et al., 2015). As a result, digital 
DOI: $\underline{10.51386 / 25815946 / \text { ijsms-v4i6p102 }}$

Volume: 4 Issue: 6

November to December 2021

https://www.ijsmsjournal.org

transformation enables the creation of new ideas and communications among business partners in the value chain. Building network externalities generated using digital technology or processes, organizations can achieve greater supply chain visibility, knowledge transfer, and operational efficiency (Bharadwaj et al., 2013; Westerman et al., 2014). Therefore, we hypothesize as follows:

H2: Digital transformation has an effect positive on SME Innovation Province Bali.

THE EFFECT OF DigIT AL INNOVATION ON SMEs INNOVATION PROVINCE BALI

The impact of innovation on firm performance has been noted in previous literature (Hsu \& Sabherwal 2012; Wang \& Wang 2012). In an increasingly competitive and uncertain business environment, innovation has emerged as an important means of survival and development for businesses (Grønhaug et al., 1988). Innovation increases organizational efficiency, adds potential value and brings intangible resources to the company (Wang \& Wang, 2012). Companies with greater innovation are more responsive to customer needs and are able to develop more capabilities that lead to better performance (Calantone et al., 2002). Therefore, we hypothesize as follows:

H3: Digital transformation has an effect positive on SME Innovation province Bali.

\section{RESEARCH METHODS}

This study uses quantitative methods to solve problems related to the phenomenon of low SME performance due to the covid19 pandemic. Data was collected using a questionnaire instrument, which will be distributed randomly to SME managers throughout the province of Bali. The province of Bali was chosen because Bali is the centre of tourism destinations in Indonesia, so that with the Covid-19 pandemic, Bali tourism has become threatened which ultimately has an impact on the SME sector as a tourism supporter. The number of SMEs recorded at the Bali Province Cooperatives and SMEs Service is 326,000 spread across all regencies/cities. The number of samples is determined by the Slovin formula at the error threshold of $5 \%$ obtained a sample of 400 SMEs.

The SME performance variable is measured using an instrument consisting of 4 indicators, namely 1) profitability, 2) Retention customer, 3) Return on Investment and 4) Sales growth (Tippins \& Sohi 2003, Nwankpa \& Roumani, 2016, (Wahyudiati, 2017). Variable digital transformation is measured by 3 items, namely 1) new business processes built on digital technology, 2) integration of digital technology 3) shifting business operations towards the use of digital technology (Aral \& Weill 2007, Nwankpa \& Roumani, (2016) Digital innovation variables are measured with two items, namely 1) Developing and producing new products or services continuously, 2) Prioritizing efforts to improve the quality of products or services (Hsu \& Sabherwal 2012, Nwankpa \& Roumani, 2016) then the conceptual framework can be made as follows:

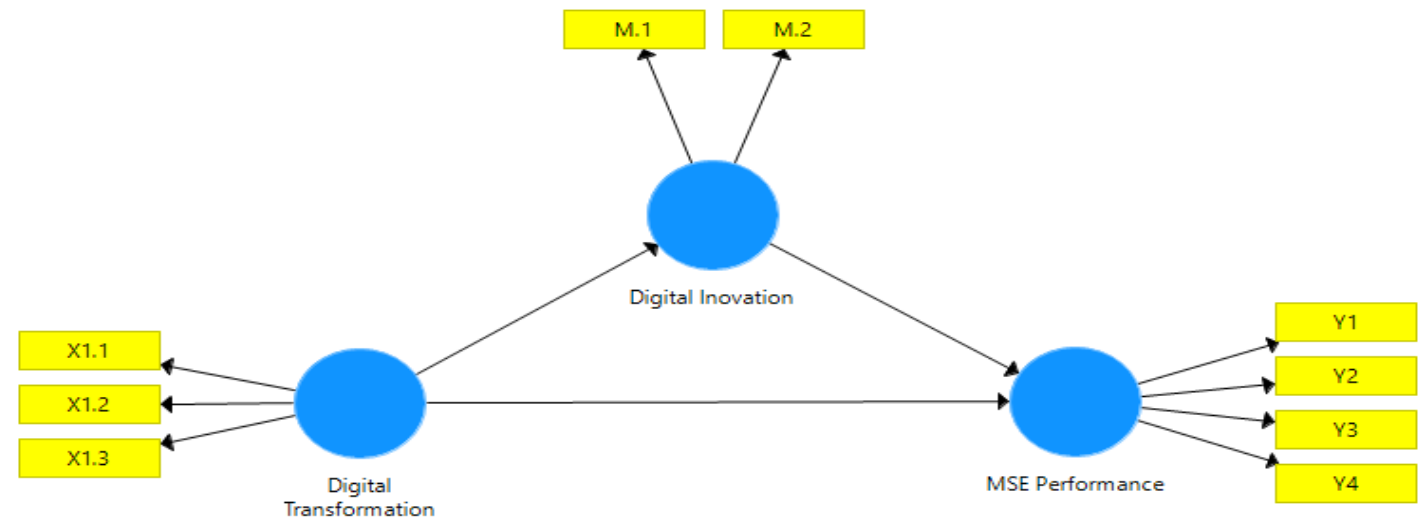

Figure 1. Conceptual Framework 
DOI: $\underline{10.51386 / 25815946 / \mathrm{ijsms}-\mathrm{v} 4 \mathrm{i} 6 \mathrm{p} 102}$

Volume: 4 Issue: 6

November to December 2021

https://www.ijssmsjournal.org

Empirical analysis and validation of the research model was carried out by using Partial Least Square (PLS) analysis. PLS was chosen because of its ability to define and test path models with latent constructs and PLS does not require the assumption of multivariate normality (Chin et al., 2001; Hair et al., 1998) and is suitable for complex models with latent variables. This research uses SmartPLS 3.2.9 software for its analysis. The bootstrap procedure was used to assess the statistical significance of the loading and path coefficients. Bootstrapping is a non-parametric approach to estimation by doing resampling original data with substitutions to obtain estimates for each parameter in the PLS model (Chin, 2001, Ghozali, 2021)). The hypothesis is supported if the measurement model reports acceptable levels of reliability, convergent and discriminant validity, and if the estimated structural path parameters are statistically significant.

\section{RESULTS AND DISCUSSION}

Characteristics of Research Respondents

This research was conducted using a survey method on 400 respondents from SMEs throughout the province of Bali. The characteristics of the respondents in this study's: 1) the age characteristics of the respondents in this study were dominated by respondents aged 31-40 years as many as 259 respondents or $64.8 \%$. 2) The gender characteristics of the respondents in this study were dominated by men as many as 213 respondents or 53.3\%. 3) The educational characteristics of the respondents in this study were dominated by the education level of SMA/SMK as many as 307 respondents or 78.6\%. and 4) The characteristics of the length of business of the respondents in this study were dominated by respondents with a length of business of 7-9 years as many as 216 respondents or $54 \%$.

\section{Measurement Model and Construct Validity}

We perform various forms of testing related to the psychometric properties of the measurement model. The instruments used in this study were assessed from convergent validity, reliability and discriminant validity. First, confirmatory factor Analysis (CFA) was performed for all latent variables in the structural model. The results of the CFA test in Table 1 show good convergent validity, this is indicated by all indicators having an outer loading above 0.70 and an AVE value of at least 0.50 as suggested (Hair et al., 2016). Second, the reliability of the measurement model (reliability) can be assessed from Cronbach alpha ( $\alpha$ ) and composite reliability (CR) exceeds the lower threshold of 0.70 as suggested by Hair et al., (2016). Thus, the variables in this study are considered quite reliable (Hair et al., 2016). Third, to test the discriminant validity, we tested the square root value of the Average Variance Extracted (AVE). To meet good discriminant validity, the square root of the AVE for each variable must be higher than the correlation between that variable and other variables in the model (Fornell \& Larcker, 1981). Validity test results discriminant in Table 2 show all of the above requirements have been met.

Table 1. Measurement Model

\begin{tabular}{|l|c|c|c|c|}
\hline \multicolumn{1}{|c|}{ Variable } & Loading & A & CR & AVE \\
\hline Digital Innovation & & 0.883 & 0.945 & 0.895 \\
\hline M.1 & 0.944 & & & \\
\hline M.2 & 0.948 & & & \\
\hline Digital Transformation & & 0.889 & 0.930 & 0.817 \\
\hline X1.1 & 0.921 & & & \\
\hline X1.2 & 0.921 & & & \\
\hline X1.3 & 0.869 & & & \\
\hline MSE Performance & & 0.889 & 0.853 & 0.593 \\
\hline Y1 & 0.833 & & & \\
\hline
\end{tabular}


DOI: $\underline{10.51386 / 25815946 / \mathrm{ijsms}-\mathrm{v} 4 \mathrm{i} 6 \mathrm{p} 102}$

Volume: 4 Issue: 6

November to December 2021

https://www.ijssmsjournal.org

\begin{tabular}{|l|l|l|l|l|}
\hline Y2 & 0.812 & & & \\
\hline Y3 & 0.705 & & & \\
\hline Y4 & 0.724 & & & \\
\hline
\end{tabular}

Table 2. Discriminant validity

\begin{tabular}{|l|c|c|c|}
\hline Indicator & $\begin{array}{c}\text { Digital } \\
\text { Innovation }\end{array}$ & $\begin{array}{c}\text { Digital } \\
\text { Transformation }\end{array}$ & $\begin{array}{c}\text { MSE } \\
\text { Performance }\end{array}$ \\
\hline Digital Innovation & $\mathbf{( 0 . 9 4 6 )}$ & & \\
\hline Digital Transformation & 0.386 & $\mathbf{( 0 . 9 0 4 )}$ & \\
\hline MSE Performance & 0.517 & 0.533 & $\mathbf{( 0 . 7 7 0 )}$ \\
\hline
\end{tabular}

Notes.

The diagonal value (in brackets) is the square root of AVE, the value of under diagonal is the correlation between variables.

\section{Structural Model Testing}

In PLS analysis, structural moddel testing is performed by testing the structural path and R2 scores of endogenous variables to assess the explanatory power of the structural model. The bootstrap procedure was performed with 400 cases and 5,000 resampling used to test the significance of all pathways in the research model (Hair et al., 2016). The results of the structural model are shown in Figure 2. The results show that the model is able to explain $39.8 \%$ of the variation in SME performance. Overall, all hypotheses are supported. To support hypothesis 1, digital transformation has a significant positive effect on SME performance $(\beta=0.392, p$ $<0.000)$. Similarly, to support hypothesis 2 , digital transformation has a positive and significant effect on digital innovation $(\beta=0.386, \mathrm{p}<0.000)$,

Table 3. Discriminant validity

\begin{tabular}{|l|c|c|c|}
\hline Relationship Between Variables & $\begin{array}{l}\text { Original } \\
\text { Sample }\end{array}$ & T Statistics & P Values \\
\hline Digital Innovation -> MSE Performance & 0.366 & 5.554 & 0.000 \\
\hline Digital Transformation -> Digital Innovation & 0.386 & 7,610 & 0.000 \\
\hline Digital Transformation -> MSE Performance & 0.392 & 7,066 & 0.000 \\
\hline
\end{tabular}

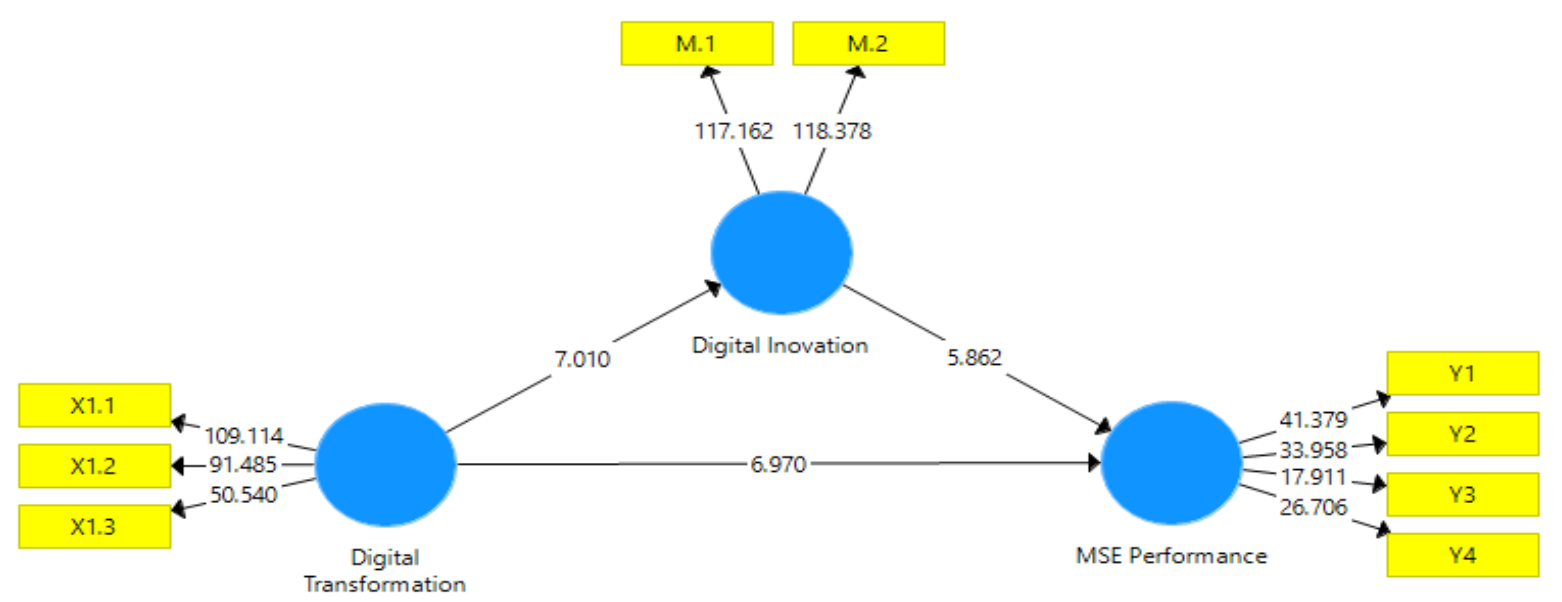

Figure 2. Structural Model Test Results 


\section{DOI: $\underline{10.51386 / 25815946 / i j s m s-v 4 i 6 p 102}$}

Digital Inovation Mediation Effect

To test mediating effect, we used the Variance Accounted For (VAF) method developed by Preacher \& Hayes, (2008) in Ghozali, (2021). Based on the results of the path analysis test in Table 3 and Figure 2, it is found that all assumptions in the VAF test have been fulfilled, namely all paths, both direct and indirect effects, are significant. The VAF calculation is then carried out as follows: VAF $=(\mathrm{p} 1 * \mathrm{p} 2) /(\mathrm{p} 1 * \mathrm{p} 2)+\mathrm{p} 3=(0.386 * 0.392) /$ $(0.386 * 0.392)+0.366=0.29$. The VAF value is 0.29 , it can be concluded that the digital innovation variable partially mediates the relationship between digital transformation and the performance of SMEs.

\section{CONCLuSIONS}

This study examines the mediating role of digital innovation in the relationship between digital transformation and SME performance. Using the RBV theory, the theoretical framework that explains the effects of digital transformation is tested using a survey of 400 SME managers throughout the province of Bali. Consistent with our proposed model, this study finds that digital transformation positively influences digital innovation. This research study finds empirical support for most of the evidence for digital innovation on SME performance. Massive internal competition marked by the emergence of so many digital technologies from social media to mobile platforms to big data, SMEs can drive performance by using digital technology to encourage the convergence of people, businesses, and things that have never happened before, especially during the Covid-19 pandemic. This finding is very interesting because it pays attention to the importance of digital transformation in supporting and driving company performance. Companies investing in digital transformation can align digital insights about their customers with innovative processes and investments that lead to improved customer experience and performance

\section{ACKNOWLEDGMENT}

We express our deepest gratitude to the Directorate General of Higher Education, Ministry of Education and Culture RI, for the Research Grant in the 2021 fiscal year.

\section{REFERENCES}

[1] Abrell, T., Pihlajamaa, M., Kanto, L., Vom Brocke, J., \& Uebernickel, F. (2016). The role of users and customers in digital innovation: Insights from B2B manufacturing firms. Information and Management. https://doi.org/10.1016/j.im.2015.12.005

[2] Agarwal, R., Gao, G. G., DesRoches, C., \& Jha, A. K. (2010). The digital transformation of healthcare: Current status and the road ahead. In Information Systems Research. https://doi.org/10.1287/isre.1100.0327

[3] Amit, R., and Schoemaker, P. H. 1993. "Strategic Assets and Organizational Rent," Strategic Management Journal, 14, pp. 33-46

[4] Barney, J. B. 1986. "Strategic factor markets: Expectations, luck, and business strategy," Management science, (32:10), pp. $1231-1241$

[5] Barney, J. 1991. "Firm resources and sustained competitive advantage,” Journal of Management, (17:1), pp. 99-120

[6] Bharadwaj, A. S. 2000. “A resource-based perspective on information technology capability and firm performance: an empirical investigation,” MIS quarterly, pp. 169-196

[7] Calantone, R. J., Cavusgil, S. T., \& Zhao, Y. (2002). Learning orientation, firm innovation capability, and firm performance. Industrial Marketing Management. https://doi.org/10.1016/S0019-8501(01)00203-6

[8] Chan, Y. 2000. "IT Value: The Great Divide between Qualitative and Quantitative and Individual and Organizational Measures," Journal of Management Information Systems, (16:4), pp. 225-261

[9] Cao, M., \& Zhang, Q. (2011). Supply chain collaboration: Impact on collaborative advantage and firm performance. Journal of Operations Management. https://doi.org/10.1016/j.jom.2010.12.008

[10] Cao, M., and Zhang, Q. 2011. "Supply chain collaboration: Impact on collaborative advantage and firm performance.” Journal of Operations Management, (29:3), pp. 163-180

[11] Cho, H., and Pucik, V. 2005. "Relationship between innovativeness, quality, growth, profitability, and market value," Strategic Management Journal, (26:6), pp. 555-575

[13] Datta, P., \& Roumani, Y. (2015). Knowledge-acquisitions and post-acquisition innovation performance: A comparative hazards model. European Journal of Information Systems. https://doi.org/10.1057/ejis.2014.32 
DOI: $\underline{10.51386 / 25815946 / \mathrm{ijsms}-\mathrm{v} 4 \mathrm{i} 6 \mathrm{p} 102}$

Volume: 4 Issue: 6

November to December 2021

https://www.ijssmsjournal.org

[14] Henfridsson, O., Nandhakumar, J., Scarbrough, H., \& Panourgias, N. (2018). Recombination in the open-ended value landscape of digital innovation. Information and Organization. https://doi.org/10.1016/j.infoandorg.2018.03.001

[15] Karagiannaki, A., Vergados, G., \& Fouskas, K. (2017). The Impact Of Digital Transformation In The Financial Services Industry : Insights From An Open Innovation Initiative In Fintech In Greece. Mediterranean Conference on Information Systems (MCIS) 2017 Proceedings

[16] Kohli, R., and Grover, V. 2008. "Business value of IT: An essay on expanding research directions to keep up with the times," Journal of the Association for Information Systems, (9:1), pp. 1.

[17] Libert, B., Beck, M., and Wind, Y. 2016. "7 Questions to ask before your next digital transformation,”

[18] Harvard Business Review, July 2016

[19] Majchrzak, A., Lynne Markus, M., \& Wareham, J. (2016). Designing for digital transformation: Lessons for information systems research from the study of ICT and societal challenges. MIS Quarterly: Management Information Systems. https://doi.org/10.25300/MISQ/2016/40

[20] Markus, M. L., \& Loebbecke, C. (2013). Commoditized digital processes and business community platforms: New opportunities and challenges for digital business strategies. In MIS Quarterly: Management Information System

[21] March, J. G., and Sutton R. I. 1997. “Organizational Performance as a Dependent Variable,” Organization Science, (8:6), pp. 698-706

[22] Markus, M. L., and Loebbecke, C. 2013. "Commoditized digital processes and business community platforms: new opportunities and challenges for digital business strategies," MIS Quarterly, (37:2), pp.649-654

[23] Nwankpa, J. K., \& Roumani, Y. (2016). IT capability and digital transformation: A firm performance perspective. 2016 International Conference on Information Systems, ICIS 2016

[24] Nambisan, S., Lyytinen, K., Majchrzak, A., \& Song, M. (2017). Digital Innovation Management: Reinventing Innovation Management Research in a Digital World. MIS Quarterly. https://doi.org/10.25300/misq/2017/41:1.03

[25] Prince, K., Barrett, M., \& Oborn, E. (2014). Dialogical strategies for orchestrating strategic innovation networks: The case of the Internet of Things. Information and Organization. https://doi.org/10.1016/j.infoandorg.2014.05.001

[26] Pramuki, N. M. W. A., \& Kusumawati, N. P. A. (2021, May). The Influence of Product Innovation, Digital Marketing and Competitive Advantage in Improving the Marketing Performance of Small and Medium Industries in Bali. In 2nd International Conference on Business and Management of Technology (ICONBMT 2020) (pp. 248-254). Atlantis Press

[27] Radhakrishnan, A., Zu, X., and Grover, V. 2008. "A process-oriented perspective on differential business value creation by information technology: An empirical investigation," Omega, (36:6), pp. 1105-1125.

[28] Ravichandran, T., Lertwongsatien, C., and Lertwongsatien, C. 2005. "Effect of information systems resources and capabilities on firm performance: A resource-based perspective," Journal of management information systems, (21:4), pp. 237-276

[29] Saarikko, T., Westergren, U. H., \& Blomquist, T. (2020). Digital transformation: Five recommendations for the digitally conscious firm. Business Horizons, 63(6), 825-839. https://doi.org/10.1016/j.bushor.2020.07.005

[30] Verganti, R. (2016). The innovative power of criticism. In Harvard Business Review

[31] Vial, G. (2019). Understanding digital transformation: A review and a research agenda. Journal of Strategic Information Systems, 28(2), 118-144. https://doi.org/10.1016/j.jsis.2019.01.003

[32] Wade, M., and Hulland, J. 2004. "Review: The resource-based view and information systems research: Review, extension, and suggestions for future research,” MIS Quarterly, (28:1), pp. 107-142

[33] Wang, Z., \& Wang, N. (2012). Knowledge sharing, innovation and firm performance. Expert Systems with Applications, 39(10), 8899-8908. https://doi.org/10.1016/j.eswa.2012.02.017

[34] Widnyani, N. M., Astitiani, N. L. P. S., \& Putri, B. C. L. (2021). Penerapan Transformasi Digital Pada UKM Selama Pandemi Covid-19 Di Kota Denpasar. Jurnal Ilmiah Manajemen Dan Bisnis, 6(1). https://doi.org/10.38043/jimb.v6i1.3093

[35] Westerman, G., Bonnet, D., \& Mcafee, A. (2014). The Nine Elements of Digital Transformation Opinion \& Analysis • January 07, $2014 \cdot$ Reading Time: 10 min. MIT Sloan Management Review

[36] Westergren, U. H., Holmström, J., \& Mathiassen, L. (2019). Partnering to create IT-based value: A contextual ambidexterity approach. Information and Organization. https://doi.org/10.1016/j.infoandorg.2019.100273

[37] Westerman, G., Bonnet, D., and McAfee, A. 2014. Leading Digital: Turning Technology into Business Transformation, Harvard Business Press 